DOI: 10.17707/AgricultForest.61.1.02

\author{
Sanita ZUTE, Linda BRUNAVA, Inga JANSONE, Ylle TAMM ${ }^{I}$
}

\title{
INFLUENCE OF FARMING SYSTEM, NITROGEN RATES AND METEOROLOGICAL CONDITIONS ON NAKED OAT IN LATVIA
}

\begin{abstract}
SUMMARY
Research and development related to the naked oat is now becoming more wide-spread as the opportunity for its different uses is understood also in Latvia. It has been recognized as a more valuable product in the food industry because both the interest of consumers in their health and the promotion of food products are increasing. Naked oat kernels contain high levels of $\beta$-glucans and unsaturated fatty acids. The aim of the study was to evaluate the yield and oat grain quality of naked oat breeding lines from Latvian oat breeding program. The following parameters were assessed - grain yield, 1000 grain weight, test weight, crude protein fat and $\beta$-glucan. The research assessed the variability of these parameters in organic and conventional farming system (at three different mineral fertilizer rates: N80, N120, N160). The field experiments were carried out at the State Stende Cereal Breeding Institute during three years (2011- 2013). Results showed that the higher $\mathrm{N}$ fertilizer rate positively affects the amount of the crude protein and $\beta$-glucan in naked oat grains. The farming system $\left(\eta^{2}=42.9\right.$ $\%)$ and testing year/meteorological condition of years $\left(\eta^{2}=35.9 \%\right)$ had a greater impact on naked oat yield. Comparing only N80, N120 and N160 variants in conventional system it was observed that during the three year period the meteorological conditions had the greatest impact on the yield of naked oat $\left(\eta^{2}=86.6 \%\right)$. Naked oat line ' $\mathrm{S}-156$ ' gave the highest grain yield in conventional and organic farming systems and formed significantly higher crude protein, fat and $\beta$-glucan amounts in the grain.
\end{abstract}

Keywords: oat qualiy, organic and conventional farming systems, $\mathrm{N}$ rates, meteorological conditions, productivity.

\section{INTRODUCTION}

Oat (Avena sativa L.) is an important contributor to food production and the economy in Europe. Naked oat (N/O) research and development is now becoming more wide-spread and naked oat as a product has various end uses also in Latvia. Around the world N/O is most often used for fodder, however, its chemical content and nutritional value have stirred interest about the use of N/O in the food products as well (Tawari, 2012; Behall, 2011; Redaelli et.al.,2009 ).

\footnotetext{
${ }^{1}$ Sanita ZUTE (corresponding author: e-mail:sanita.zute@stendeselekcija.lv), Linda BRUNAVA, Inga JANSONE, Ylle TAMM, State Stende Cereals Breeding Institute, Latvia.
}

Paper presented at the $5^{\text {th }}$ International Scientific Agricultural Symposium "AGROSYM 2014".

Notes: The authors declare that they have no conflicts of interest. Authorship Form signed online. 
In the recent years the research on the content of naked barley and oat and their use in food production has been also carried out in Latvia (Bleidere et. al., 2012; Zute et. al., 2012; Rakcejeva et.al., 2007), but there is still a lot to learn.

$\mathrm{N} / \mathrm{O}$ might be used as an ingredient in such products. N/O grows and looks like traditional oat until it is nearly mature. The glumes begin to separate from the seed when it is almost mature and become totally separated when the grain is combined. Unlike covered oat it is possible to use it in food products directly without de-husking. N/O kernels has a smaller amount of thousand grain weight (TGW), but higher amount of volume weight (VW) than covered oats. N/O kernels contain high levels of $\beta$-glucans and much of the research on the healthpromoting properties of oat has focused on mechanisms that involve $\beta$-glucans (Zute et. al., 2012; Wood, 2011).

In the breeding of varieties it is important to pay attention to both the characteristics that are essential for the processing industry and the ability of the varieties to adapt to the conditions of growing. Nitrogen is commonly the most limiting nutrient for crop production therefore adoption of good $\mathrm{N}$ management strategies often result in large economic benefits to farmers. The rate of uptake and partition of $\mathrm{N}$ is largely determined by supply and demand during various stages of plant growth (Amanullah et al., 2008). During grain filling, the nitrogen accumulated in the vegetative organs is remobilized to the ear. Up to $95 \%$ of grain $\mathrm{N}$ comes from the remobilization of $\mathrm{N}$ stored in roots and shoots before anthesis. After flowering, both the size and the $\mathrm{N}$ content of the grain can be significantly reduced under $\mathrm{N}$ deficient conditions (Triboi et.al., 2002).

As the reduction of environmental pollution caused by agriculture nowadays is becoming a more and more important issue, the more effective farming techniques also gain the importance as a research object, including also those using plant varieties that have better nitrogen use efficiency. Organic farming system (OFS) is best placed to respond to the challenges of effective nitrogen management. (Hirel et al., 2011). Growing of N/O could open up new possibilities in use of oat varieties and increase the demand and interest of producers and growers including OFS and organic products. In the process of developing new N/O varieties, identifying the genotypes, that can provide as high the yield as possible and ensure grain quality at lower $\mathrm{N}$ rates, would be an important breeding trait.

There is little information in scientific publications on experiments that have examined the influence of agronomic factors in N/O. (Givens et al., 2004; Danyte, 2013, Lawes, 1974). Such knowledge is crucial for the design of both OFS and conventional farming system (CFS) technologies.

It is unknown how the N/O yield and grain quality will be affected by meteorological conditions in Latvia and by different management conditions. The aim of the study was to evaluate the yield and grain quality variation of two N/O genotypes under CFS conditions with different rates of N and OFS conditions without $\mathrm{N}$ application. 


\section{MATERIAL AND METHODS}

The field experiment. The field experiments were carried out at the State Stende Cereal Breeding Institute during the three meteorologically different years (2011, 2012 and 2013). The experimental treatment consisted of 9 factorial combinations of two naked oat genotypes 'S-156'; 'ST 33793' and three N rates N80; N120; N160 in the conventional growing conditions and separately without fertilizer application under organic growing conditions. Complex fertilizer N16P16-K16 in the amount of $500 \mathrm{~kg} \mathrm{ha}^{-1}$ was used as a basic fertilizer in the conventional field trial. The $\mathrm{N}$ application was split, part of the $\mathrm{N}$ being applied at the time of sowing and the remaining half at the end of tillering stage (growing stage/GS 29) of the crop. Amonium nitrate (N 34\%) was used as a top-fertilizer in the following amount: $40 \mathrm{~kg} \mathrm{~N} \mathrm{ha}^{-1}$ (N120) and $80 \mathrm{~kg} \mathrm{~kg} \mathrm{~N} \mathrm{ha}^{-1}$ (N160). The treatments were laid out in a randomized complete block design; the plot size was $10 \mathrm{~m}^{2}, 4$ replicates.

The oat was sown in a well prepared seedbed at a rate of 500 germinating seeds per $\mathrm{m}^{2}$.

Soil and weather characteristics. The soil under conventional growing was sod-podzolic sandy loam, content of organic substance $21-23 \mathrm{~g} \mathrm{~kg}^{-1}$, the soil $\mathrm{pH}$ KCL 5.5-5.9, the content of phosphorus $\mathrm{P}_{2} \mathrm{O}_{5}$ available for plants 200-241 mg $\mathrm{kg}^{-1}$, and potassium $\mathrm{K}_{2} \mathrm{O}$ 169-237 $\mathrm{mg} \mathrm{kg}^{-1}$. The soil under organic growing conditions in both years was sod-podzolic sandy loam, content of organic substance 21-24 $\mathrm{g} \mathrm{kg}^{-1}$, the soil pH KCL 5.6-6.0, the content of plant-available phosphorus $\mathrm{P}_{2} \mathrm{O}_{5} 171-209 \mathrm{mg} \mathrm{kg}^{-1}$, and potassium $\mathrm{K}_{2} \mathrm{O}-122-153 \mathrm{mg} \mathrm{kg}^{-1}$.

Overall the growing seasons of 2011 can be characterized by the average temperature above the long-term data and some extreme periods of drought (Table 1). In 2011 hot and dry conditions were observed during the last ten days of May and the first ten days of June. The average temperature was above the long-term data for June $\left(2.6^{\circ} \mathrm{C}\right)$ and July $\left(2.9^{\circ} \mathrm{C}\right)$ (Table 1$)$. The growing season of 2012 can be characterized as having optimal temperature and moisture conditions, and a smaller number of sunny days. The moisture and temperature conditions during early stages of plant development were optimal. A lot of rainy and cloudy days during May and June contributed to a slow oat growth and development. Also in July and August there were more precipitations than usual. The April of 2013 was colder than usual. The snow melted only during the second ten day period of April, but at the beginning of May the temperature during the day reached $+20^{\circ} \mathrm{C}$. The average temperature was above the long-term data also in the other months that were important for the plant development. An especially high temperature was observed during the last ten days of July and the first days of August when the temperature during the day exceeded $30^{\circ} \mathrm{C}$. The year 2013 was also peculiar as regards the distribution of precipitation. The greatest amount of precipitation was observed in May and June during which the amount of precipitation is usually smaller, whereas in July and August the amount of precipitation was significantly lower than in 2011 and 2012 and 
approximately twice lower than the average of long-term data for this time of the year.

Table 1. Average temperatures and sums of precipitation in each month, Stende, $2011-2013$

\begin{tabular}{|l|c|c|c|c|c|c|c|c|}
\hline \multirow{2}{*}{ Month } & \multicolumn{4}{|c|}{ Average temperature, ${ }^{\circ} \mathrm{C}$} & \multicolumn{3}{c|}{ Sums of precipitation, $\mathrm{mm}$} \\
\cline { 2 - 10 } & 2011 & 2012 & 2013 & norm & 2011 & 2012 & 2013 & norm \\
\hline April & 6.9 & 5.6 & 4.0 & 4.3 & 26.8 & 42.7 & 34.9 & 37 \\
\hline May & 10.6 & 11.0 & 13.7 & 10.2 & 54.7 & 58.9 & 86.1 & 45 \\
\hline June & 16.8 & 13.2 & 16.9 & 14.2 & 59.6 & 78.7 & 74.5 & 57 \\
\hline July & 19.2 & 17.5 & 16.9 & 16.3 & 165.3 & 91.7 & 36.2 & 87 \\
\hline August & 16.3 & 15.5 & 16.6 & 15.5 & 155.0 & 115.1 & 45.2 & 87 \\
\hline Average/Sum & 14.0 & 12.6 & 13.6 & 12.1 & 461.4 & 387.1 & 276.9 & 313 \\
\hline
\end{tabular}

Sampling, chemical and statistical analysis. The grain yield was measured for each basic plot, and the samples for analyzing grain quality were taken from each variant. The following grain physical traits were evaluated: 1000 grain weight (TGW, g) by ISTA method, volume weight (VW, $\mathrm{g} \mathrm{L}^{-1}$ ) by automatic grain analyzer Infratec Analysis 1241. Also crude protein content (CP, $\mathrm{g} \mathrm{kg}^{-1}$ ), fat content $\left(\mathrm{CF}, \mathrm{g} \mathrm{kg}^{-1}\right.$ ) and $\beta$-glucans content (BGL, $\mathrm{g} \mathrm{kg}^{-1}$ ) were analyzed by automatic grain analyzer Infratec Analysis 1241 .

ANOVA procedures were used for statistical data analysis. In the analysis of variance, the partitioning of sum of squares $\left(\eta^{2}\right)$ due to the relative impact of each single factor was estimated. The significance of effect of factors was determined at a probability level of 0.05 .

\section{RESULTS}

Grain yield. ANOVA analysis of variance showed that the factors that had the highest impact on the yield of naked oats during the three year period, were meteorological conditions during the experiment year $\left(\eta_{A}{ }_{A}=42.9 \%\right)$ and the choice of growing system $\left(\eta^{2}=35.9 \% ; \eta^{2}{ }_{A B}=15.4 \%\right)$ (Table 2$)$. There were significant differences in the average yield of both $\mathrm{N} / \mathrm{O}$ varieties in organic and conventional farming systems in all three years of experiments $\left(\operatorname{LSD}_{0.05}^{\mathrm{B}}=0.13\right)$. The average N/O yield in organic system did not vary essentially during the years - from 1.90 to $2.02 \mathrm{t} \mathrm{ha}^{-1}\left(\mathrm{LSD}_{0.05}^{\mathrm{C}}=0.11 \mathrm{t} \mathrm{ha}^{-1}\right.$ ) (Table 2). The highest yield in the organic system was obtained in 2011 from the breeding line ' $\mathrm{S}-156$ ' $-2.27 \pm$ $0.121 \mathrm{t} \mathrm{ha}^{-1}$ (Table 3).

Comparing the $\mathrm{N} / \mathrm{O}$ productivity in the conventional system at three different $\mathrm{N}$ rates it was observed that from year to year the $\mathrm{N} / \mathrm{O}$ yield varied from 2.53 to $5.53 \mathrm{t} \mathrm{ha}^{-1}$ (Table 3). The $\mathrm{N} / \mathrm{O}$ reaction to the increase of $\mathrm{N}$ dose differed from year to year. In 2011 the yield of variant N160 was significantly smaller than that of N80 and N120. In 2012 the highest yield was obtained from the variant N120. In 2013 a significant increase of the N/O yield was obtained from all variants of $\mathrm{N}$ rate. During the three year period the average productivity of 
each $\mathrm{N}$ rate shows that the highest yield of both $\mathrm{N} / \mathrm{O}$ breeding lines was at the rate N120, 'S-156' $-4.26 \pm 0.127 \mathrm{t} \mathrm{ha}^{-1}$ and 'S-33793' $-3.84 \pm 0.168 \mathrm{t} \mathrm{ha}^{-1}$ respectively (Table 3 ).

Table 2. Partitioning of sum of squares $\left(\eta^{2}\right)$ of measured traits for naked oat genotypes under different farming systems, 2011 - 2013

\begin{tabular}{|l|c|c|c|c|c|c|}
\hline \multicolumn{1}{|c|}{ Factors } & Yield & TGW & VW & CP & CF & BGL \\
\hline Years - factor A & $35.9^{*}$ & $9.9^{*}$ & $74.3^{*}$ & $18.1^{*}$ & $43.5^{*}$ & $70.7^{*}$ \\
\hline $\begin{array}{l}\text { Farming systems** } \\
\text { - factor B }\end{array}$ & $42.9^{*}$ & $54.2^{*}$ & $5.6^{*}$ & $51.5^{*}$ & $9.3^{*}$ & $8.5^{*}$ \\
\hline Genotypes - factor C & $1.3^{*}$ & 0.1 & $2.7^{*}$ & $4.9^{*}$ & $39.0^{*}$ & $0.5^{*}$ \\
\hline A x B & $15.4^{*}$ & $17.1^{*}$ & $10.5^{*}$ & $12.0^{*}$ & 0.5 & $5.1^{*}$ \\
\hline A x C & $0.4^{*}$ & $1.9^{*}$ & 0.2 & $3.5^{*}$ & $2.8^{*}$ & $1.5^{*}$ \\
\hline B x C & 0.1 & 0.2 & 0.3 & $0.5^{*}$ & $0.7^{*}$ & $1.1^{*}$ \\
\hline A x B x C & $1.4^{*}$ & 1.0 & $1.3^{*}$ & $6.8^{*}$ & 0.3 & $5.5^{*}$ \\
\hline
\end{tabular}

*Significant at 5\%; TGW - 1000 grain weight; VW - volume weight; $\mathrm{CP}$ - crude protein; $\mathrm{CF}$ crude fat; BGL - $\beta$-glucan;

**Farming systems: OFS N0 - organic farming systems without nitrogen fertilizer, CFS conventional farming system with different nitrogen doses (N80, N120, N160)

Table 3. Variation of grain yield for naked oat genotypes under different rates of $\mathrm{N}$ application and farming systems, 2011 - 2013

\begin{tabular}{|c|c|c|c|c|c|}
\hline \multirow{2}{*}{$\begin{array}{c}\text { Testing } \\
\text { years } \\
\text { (Factor A) }\end{array}$} & \multirow{2}{*}{$\begin{array}{c}\text { Farming } \\
\text { system and N } \\
\text { doses } \\
(\text { Factor B) }\end{array}$} & \multicolumn{3}{|c|}{ Oat breeding lines (Factor $\mathrm{C}$ ) } & \multirow[b]{2}{*}{ Mean A } \\
\hline & & S-156 & S-33793 & Mean B & \\
\hline \multirow{4}{*}{2011} & $\mathrm{OS}-\mathrm{N} 0$ & 2.27 & 1.76 & 2.02 & \multirow{4}{*}{2.73} \\
\hline & $\mathrm{CS}-\mathrm{N} 80$ & 3.13 & 3.18 & 3.16 & \\
\hline & $\mathrm{CS}-\mathrm{N} 120$ & 3.80 & 2.62 & 3.21 & \\
\hline & $\mathrm{CS}-\mathrm{N} 160$ & 2.72 & 2.34 & 2.53 & \\
\hline \multirow{4}{*}{2012} & $\mathrm{OS}-\mathrm{NO}$ & 2.06 & 1.92 & 1.99 & \multirow{4}{*}{2.99} \\
\hline & $\mathrm{CS}-\mathrm{N} 80$ & 3.58 & 2.85 & 3.21 & \\
\hline & $\mathrm{CS}-\mathrm{N} 120$ & 3.60 & 3.50 & 3.55 & \\
\hline & CS-N160 & 3.18 & 3.28 & 3.23 & \\
\hline \multirow{4}{*}{2013} & $\mathrm{OS}-\mathrm{NO}$ & 1.97 & 1.84 & $1.90^{*}$ & \multirow{4}{*}{4.45} \\
\hline & $\mathrm{CS}-\mathrm{N} 80$ & 5.11 & 4.88 & 4.99 & \\
\hline & $\mathrm{CS}-\mathrm{N} 120$ & 5.40 & 5.38 & 5.39 & \\
\hline & CS-N160 & 5.63 & 5.43 & 5.53 & \\
\hline \multicolumn{2}{|r|}{ Mean $\mathrm{C}$} & 3.54 & 3.25 & \multirow[b]{2}{*}{$\begin{array}{c}\mathrm{LSD}^{\mathrm{B}}{ }_{0.05}=0.1 \\
3\end{array}$} & \multirow[b]{2}{*}{$\begin{array}{c}\operatorname{LSD}_{0.05}^{\mathrm{A}}=0.1 \\
1\end{array}$} \\
\hline $\begin{array}{l}\text { LSD } \\
\text { LSD } \\
\text { LSD }\end{array}$ & $\begin{array}{l}0.05=0.23 \\
0.05=0.19 \\
0.05=0.16\end{array}$ & \multicolumn{2}{|c|}{$\mathrm{LSD}_{0.05}^{\mathrm{C}}=0.09$} & & \\
\hline
\end{tabular}


It proves that the efficiency of the $\mathrm{N}$ use depends to a great extent on other external factors. Comparing the change of N/O yield from year to year and the meteorological conditions during the vegetation period in the respective year (Table 1), it can be seen that the increase of $\mathrm{N}$ dose was more effective in the year during which the greatest part of precipitation was observed during the first half of the vegetation period, that is, in May and June 2013.

Evaluating the reaction of each N/O breeding line to the choice of farming system as well as the increase of $\mathrm{N}$ dose in CFS, similar tendencies were observed. Analysis of data variance shows that the influence of such a factor as a breeding lines' genotype on the yield in the field experiments was insignificant $\left(\eta^{2}=1.9 \%\right)$. Thus the reaction of N/O breeding lines' genotypes to the changes in growing conditions was similar.

Grain quality. The volume weight (VW) of the N/O grains harvested in the experiment varied from $594.5 \pm 32.62 \mathrm{~g} \mathrm{~L}^{-1}$ ('S-33793', CFS N160) to 626.3 $\pm 28.51 \mathrm{~g} \mathrm{~L}^{-1}$ ('S-156', OFS N120) (Table 4). The highest average VW during the three year period was obtained in OFS trial. The VW differences among the variants of $\mathrm{N}$ rates in CFS were statistically insignificant, but with a tendency of the grain VW to diminish when the $\mathrm{N}$ dose was increased.

Evaluating the impact of each analyzed factor on $\mathrm{VW}$, it was observed that in the experiment the N/O VW was most significantly influenced by the factor A - the meteorological conditions of the year and their combination with the factor $\mathrm{B}$ - farming system $\left(\eta^{2}{ }_{\mathrm{A}}=74.3 \% ; \eta_{\mathrm{AB}}^{2}=10.5 \%\right)$ (Table 2). The factors $\mathrm{B}$ and $\mathrm{C}$ the breeding line's genotype also had a statistically significant $(5 \%)$ impact, however the proportion of this impact on the numerical value of VW was comparatively small $\left(\eta^{2}<5 \%\right)$.

The size of grains or the weight of 1000 grains in the samples of grains obtained in the experiment varied from $27.5 \pm 1.77 \mathrm{~g}$ ('S-33793', OFS N0) to $30.01 \pm 1.04 \mathrm{~g}$ ('S-33793', CFS N160) (Table 4). The most significant differences in TGW were observed between OFS and CFS, especially for the line 'S-33703'. It was also confirmed by analysis of data variance - the factor B had the highest impact on N/O TGW - $\eta_{B}^{2}=54.2 \%$; $\eta^{2}{ }_{A B}=17.1 \%$ (Table 2). Comparing the data acquired from CFS variants, it was found that the increase of $\mathrm{N}$ doses did not have a significant impact on the changes in TGW. The most changes in TGM in these variants were caused by the factor $\mathrm{A}$ as well as a combination of factors $\mathrm{A}$ and $\mathrm{B}-\eta_{\mathrm{A}}^{2}=17.9 \% ; \eta_{\mathrm{AB}}^{2}=13.9 \%$. In the CFS variants $\mathrm{N} / \mathrm{O}$ breeding lines' genotype also had a slight, but statistically significant impact on TGW $-\eta^{2}{ }^{2}=4.7 \%$.

The crude protein amount $(\mathrm{CP})$ of the N/O breeding lines included in the experiment varied from $143.5 \pm 10.69 \mathrm{~g} \mathrm{~kg}^{-1}$ ('S-33793', OFS N0) to $175.0 \pm$ $10.15 \mathrm{~g} \mathrm{~kg}^{-1}$ ('S-156', CFS N160) (Table 5). The highest CP was found in 2012 in the variant with line ' $\mathrm{S}-156$ ' in CFS at $\mathrm{N} 160-187.5 \mathrm{~g} \mathrm{~kg}^{-1}$. Comparing the amount of $\mathrm{CP}$ in the N/O grains in the variants of OFS and CFS, it was observed that the amount of $\mathrm{CP}$ increases when the $\mathrm{N}$ dose has been increased. Evaluating 
the average variants of OFS and CFS during the three years, the CP amount was significantly higher for the variants of CFS at N120 and N160 than those of OFS at N0. Evaluating the impact of each factor on CP indicators, it was found that the $\mathrm{CP}$ depends significantly on all three factors and their combinations. The highest impact on the amount of $\mathrm{CP}$ in grains was yielded by the factor $\mathrm{B}-$ farming system, the factor $A$ and the combination of both factors $\left(\eta^{2}{ }_{B}=52.5 \%\right.$; $\eta_{\mathrm{A}}^{2}=18.1 \%, \eta_{\mathrm{AB}}^{2}=12.1 \%$ ) (Table 2).

Table 4. Variation of grain yield and physical grain quality parameters for naked oat genotypes under different growing conditions, 2011 - 2013

\begin{tabular}{|c|c|c|c|c|c|}
\hline \multirow{2}{*}{ Parameters } & \multirow{2}{*}{$\begin{array}{c}\text { Breedin } \\
\text { g lines }\end{array}$} & \multicolumn{4}{|c|}{ Farming systems } \\
\cline { 2 - 6 } & OFS - N0 & CFS - N80 & CFS - N120 & CFS - N160 \\
\hline $\begin{array}{c}\text { Yield, } \\
\mathrm{t} \mathrm{ha}^{-1} \pm \mathrm{SD}\end{array}$ & $\mathrm{S}-156$ & $2.09 \pm 0.24$ & $3.94 \pm 0.91$ & $4.26 \pm 0.88$ & $3.84 \pm 1.35$ \\
\cline { 2 - 6 } & S-33793 & $1.84 \pm 0.19$ & $3.637 \pm 0.94$ & $3.84 \pm 1.23$ & $3.68 \pm 1.36$ \\
\cline { 2 - 6 } & Mean & $1.97 \pm 0.25$ & $3.79 \pm 0.91$ & $4.05 \pm 1.07$ & $3.76 \pm 1.32$ \\
\hline \multirow{2}{*}{$\begin{array}{c}\text { TGW, } \\
\mathrm{g} \pm \mathrm{SD}\end{array}$} & $\mathrm{S}-156$ & $28.4 \pm 1.30$ & $29.6 \pm 0.90$ & $29.4 \pm 1.11$ & $29.9 \pm 0.78$ \\
\cline { 2 - 6 } & S-33793 & $27.5 \pm 1.77$ & $29.8 \pm 1.41$ & $29.5 \pm 0.97$ & $30.01 \pm 1.04$ \\
\cline { 2 - 6 } & Mean & $27.9 \pm 1.58$ & $29.7 \pm 1.16$ & $29.5 \pm 1.02$ & $29.99 \pm 0.90$ \\
\hline \multirow{2}{*}{$\begin{array}{c}\text { VW, } \\
\text { g }\end{array} \pm \mathrm{SD}$} & S-156 & $626.3 \pm 28.51$ & $617.8 \pm 24.21$ & $610.8 \pm 37.62$ & $608.9 \pm 35.47$ \\
\cline { 2 - 6 } & S-33793 & $614.3 \pm 23.86$ & $613.5 \pm 26.85$ & $600.2 \pm 39.12$ & $594.5 \pm 32.62$ \\
\cline { 2 - 6 } & Mean & $620.3 \pm 26.43$ & $615.6 \pm 25.09$ & $605.5 \pm 37.91$ & $601.7 \pm 34.12$ \\
\hline
\end{tabular}

Table 5. Variation of chemical grain quality parameters for naked oat genotypes under different growing conditions, 2011 - 2013

\begin{tabular}{|c|c|c|c|c|c|}
\hline \multirow{2}{*}{ Parameters } & \multirow{2}{*}{$\begin{array}{c}\text { Breedin } \\
\text { g lines }\end{array}$} & \multicolumn{4}{|c|}{ Farming systems } \\
\cline { 2 - 6 } & OFS - N0 & CFS - N80 & CFS - N120 & CFS - N160 \\
\hline \multirow{2}{*}{$\mathrm{g} \mathrm{kP}^{-1} \pm \mathrm{SD}$} & $\mathrm{S}-156$ & $147.8 \pm 10.78$ & $158.9 \pm 7.17$ & $170.2 \pm 9.31$ & $175.0 \pm 10.15$ \\
\cline { 2 - 6 } & $\mathrm{S}-33793$ & $143.5 \pm 10.69$ & $14.9 \pm 9.50$ & $164.8 \pm 9.47$ & $167.7 \pm 9.47$ \\
\cline { 2 - 6 } & Mean & $145.4 \pm 10.68$ & $154.3 \pm 9.49$ & $167.5 \pm 9.58$ & $171.4 \pm 11.30$ \\
\hline \multirow{2}{*}{$\begin{array}{c}\mathrm{CF}, \\
\mathrm{g} \mathrm{kg}^{-1} \pm \mathrm{SD}\end{array}$} & $\mathrm{S}-156$ & $109.3 \pm 9.33$ & $102.4 \pm 9.84$ & $102.7 \pm 11.31$ & $100.1 \pm 9.718$ \\
\cline { 2 - 6 } & $\mathrm{S}-33793$ & $94.2 \pm 5.73$ & $91.4 \pm 6.78$ & $87.3 \pm 6.88$ & $84.1 \pm 7.04$ \\
\cline { 2 - 6 } & Mean & $101.7 \pm 10.97$ & $96.9 \pm 10.01$ & $95.0 \pm 12.05$ & $92.1 \pm 11.64$ \\
\hline \multirow{2}{*}{$\begin{array}{c}\text { BGL, } \\
\mathrm{g} \mathrm{kg}^{-1} \pm \mathrm{SD}\end{array}$} & $\mathrm{S}-156$ & $36.4 \pm 5.91$ & $40.8 \pm 5.23$ & $39.2 \pm 5.63$ & $39.3 \pm 6.24$ \\
\cline { 2 - 6 } & $\mathrm{S}-33793$ & $34.1 \pm 7.13$ & $40.2 \pm 5.50$ & $38.6 \pm 6.51$ & $38.4 \pm 6.84$ \\
\cline { 2 - 6 } & Mean & $35.5 \pm 6.56$ & $40.1 \pm 5.25$ & $38.8 \pm 5.95$ & $38.8 \pm 6.41$ \\
\hline
\end{tabular}

Crude fat content $(\mathrm{CF})$ in the experiment variants during the three years ranged on average from $84.1 \pm 7.04 \mathrm{~g} \mathrm{~kg}^{-1}$ (S-33793, CFS N160) to $109.3 \pm 9.33$ 
g kg -1 ('S-156', OFS N0; Table 5), in certain years reaching even $120 \mathrm{~g} \mathrm{~kg}^{-1}$ ('S-156', OFS N0, 2013). Contrary to amount of CP in N/O grains, the CF content diminished, when the $\mathrm{N}$ dose was increased. N/O breeding line ' $\mathrm{S}-156$ ' had a significantly higher CF content in all variants of experiment than the line 'S-33793'. It was also reflected in the analysis of data variance which showed that in this trial the CF content of N/O grains was mostly affected by factors A and $\mathrm{C}\left(\eta_{\mathrm{A}}^{2}=43.5 \% ; \eta_{\mathrm{C}}^{2}=39.0 \%\right)$, while the impact of factor $\mathrm{B}$ was significantly lower $-\left(\eta^{2}=9.1 \%\right)$.

The amount of soluble fiber in N/O grains was determined from the amount of $\beta$-glucan (BGL) in the grains. The amount of BGL during the three year period varied from $34.1 \pm 7.13 \mathrm{~g} \mathrm{~kg}^{-1}$ ('S-33793', OFS N0) to $40.8 \pm 5.23 \mathrm{~g}$ $\mathrm{kg}^{-1}$ ('S-156', CFS N80) (Table 5). During the three year period the highest amount of BGL on average was observed in the N/O line 'S-156', however these differences between the lines were not statistically significant. The analysis of data variance showed that the amount of BGL in grains was most significantly affected by the factor $A-\eta_{A}^{2}=70.7 \%$, and much less by the factor $B-\eta_{B}^{2}=8.1 \%$ Table 2). The impact of the factor $\mathrm{C}$ was statistically significant, but the proportion of the impact was small $-\eta^{2}{ }_{C}=1.5 \%$. Comparing the impact of growing system on the amount of BGL in grains, it was found that in CFS its amount for both N/O lines is significantly higher than in OFS.

\section{DISCUSSION}

Important indicators for oat grain food processors are different physical indicators of oat grains - grain volume weight (WV), 1000 grain mass (TGM), percentage of husk in the yield, foreign material percentage, while little attention is paid to biochemical indicators of grains (Winfield et al., 2007; Doehlert, 2002).

According to the results of this experiment the average N/O productivity ranged from $36 \%$ (2013) in OFS to $62 \%$ (2011) in CFS at the rate N80. As in OFS the growing of N/O depends largely on the amount of nutrients, especially $\mathrm{N}$, in the soil, for OFS the crucial issue is the opportunities of ensuring additional $\mathrm{N}$ needed for the plant development, for example, by growing oat in the mixture with legumes (Neugschwandtner et al., 2014). A higher dose of $\mathrm{N}$ used in the variant CFS N160 did not ensure a regular increase of yield because it caused the lodging of oats during the periods of heavy precipitation.

TGW depends most of all on the genotype of the variety and less on the environmental conditions. However, according to long-term observations CFS, extreme growing conditions (drought, high temperature, lodgings) impacts negatively the size of oat grains (Bleidere et al., 2012; Tamm et al., 2008).

Although VW greatly depends on the sorting quality of and the environmental conditions, it is also a variety-specific characteristic. The VW of oats is affected by grain endosperm density, grain shape and size as well as on how tightly husk surround the grain. (Doehlert, 2002). The Estonian scientists have found that in CFS the amount of oat VW varies much more significantly from year to year than that of winter and summer wheat. During most dry years 
the volume weight was higher than on average (Ingver, et al., 2010). This experiment proved that also for N/O the most significant changes in the amount of $\mathrm{VW}$ from year to year were caused by the meteorological conditions during the respective year, but generally the amount of VW from year to year did not fluctuate more than $5 \%$ for all variants.

The biochemical content of oat grains determines its dietary value for food products or fodder. The dietary value of oat grains is determined by their protein and fat amount. Oats are also a valuable source of fiber; a special interest in the research has been shown about the fast solubility, for example, about the amount of $\beta$ - glucan.

The protein content of oat grains from different genotypes can greatly vary, remaining between $7-16 \%$, however the protein content in N/O grains is especially high (Peterson, 2011). In addition to variety - specific differences, oat protein content also significantly depends on environmental conditions. If plant growth is limited due to low humidity, then grain protein content is higher (Peterson, 2011, Ingver et.al. 2010). It was also found in this experiment - plants used $\mathrm{N}$ for storage of protein most effectively in 2012 during which the average temperature was high and there was little precipitation after the flowering period. The N/O breeding lines included in the experiment had high amount of crude protein in the grains, in beneficial conditions exceeding $180 \mathrm{~g} \mathrm{~kg}^{-1}$, and that is 45-70 $\mathrm{g}$ higher than the crude protein amount found in covered oat varieties which are more widely grown in Latvia (Zute et al., 2008). N/O line 'S-156' can provide high CP amount in grains also in OFS (during the three year period of the experiment - from 138 to $161 \mathrm{~g} \mathrm{~kg}^{-1}$ ); these results are significantly higher than the results of naked barley varieties and lines that were also included and evaluated in this experiment (Bleidere, et al. 2013).

The CF content in N/O grains is significantly higher than that of other cereal species, including covered oats (Behall et al., 2011). There is a negative correlation between the amount of CP and CF in the grains. Such tendency was also observed in this experiment. The highest amount of CF in N/O was obtained from the variants grown in OFS N0 which also had the lowest protein content. The oat fat is rich in unsaturated fatty acids that are important indicators for the consumers of the oat products. Sometimes the interests of producers and consumers differ. For example, the producers of oat products choose varieties with low crude fat content in order to ensure that the oat products can be stored for a longer time, while the oat products with higher content of unsaturated fatty acids have a higher nutritional value. The data of the experiment show that N/O line ' $\mathrm{S}-156$ ' has an especially high $\mathrm{CF}$ content and the $\mathrm{CF}$ value in grains obtained in OFS can in certain years exceed $120 \mathrm{~g} \mathrm{~kg}^{-1}$.

The sufficient amount of $\mathrm{N}$ plays an important role not only for the creation of yield and CP, but also for the increase of soluble fiber - BGL content in N/O grains. It is indicated in the results of different published researches (Danyte, 2013, Zute et al., 2010). Nevertheless, in this experiment one 
can see that the BGL content was even more significantly affected by the meteorological conditions during the respective year.

\section{CONCLUSIONS}

The productivity and grain quality of N/O depends significantly on the chosen farming system, especially on the indicators (yield, amount of protein and b-glucan in the grains) the value of which is closely related to the $\mathrm{N}$ amount that is provided to the plants. It is possible to obtain high quality N/O grains in OFS; the breeding line ' $\mathrm{S}-156$ ' had an especially high protein and fat content. The experiments in CFS showed that the potential productivity of this line could exceed 5 t/ha-1. It is necessary to improve the technologies of growing N/O in OFS in order to raise the productivity level and reduce the impact of meteorological conditions.

\section{ACKNOWLEDGEMENT}

This study is performed with financial support by the European Social Fund project No.2013/0072/1DP/1.1.1.2.0/13/APIA/VIAA/032.

\section{REFERENCES}

Amanullah, R.A., Khalil, S.K., 2008. Effects of plant density and N on phenology and yield of cereals. Journal of Plant Nutrition, 32, 246-260.

Bleidere M., Vīcupa Z., Zute.S., 2012. Food grain quality traits in oat under organic and conventional growth conditions. Safe Food. Proceedings of 16th International Eco-Conference. Novi Sad, Serbia, 26.-29.09.2012, pp. 353-360.

Behall K.M, Hallfrisch J., 2011. Oats as a functional foof for health. In : Oats chemistry and tehnology. Webster F.H., Wood P.J (eds). pp. 257-267

Bleidere M., Zute S., Brunava L., Bobere N., Jakobsone I., 2013. Yield and grain quality of hulless barley in field trials under diferent nitrogen managment conditions. Proceedings of the Latvian Academy of Sciences. Section B:Natural, Exact and Applied Sciences, Vol. 67, No.3, pp 229-235

Danyte V., 2013. Comparison of Advanced Oat Breeding Lines in Lithuania. Proceedings of the Latvian Academy of Sciences. Section B. Natural, Exact, and Applied Sciences. Volume 66, Issue 4-5, p. 172-176,

Doehlert, D.C., 2002. Quality improvement in oat. quality improvement in field crops. Eds. Basra, A.S., Ranhawa, L. S. Food Product Press, USA, pp.165-190.

Givens D.I., Davies T.W., Laverick R.M., 2004 Effect of variety, nitrogen fertilizer and varius agronomic factors on the nutritive value of husked and naked oat grain. Animal Feed Science and technology, 113, 169-181.

Hirel, B., Tetu T., Lea, P. J., Dubois, F., 2011. Improving Nitrogen Use Efficiency in Crops for Sustainable Agriculture. Sustainability, 3, 1452-1485

Ingver, A., Tamm, I., Tamm, Ü. Kangor, T. Koppel, R., 2010. The characteristics of spring cereals in changing weather in Estonia. Agronomy Research, Volume 8, Special issue 3, pp.553-562.

Lawes D.A., Boland P., 1974 Efect of temperature on the expression of the naked grain character in oat. Euphytica, 23, $101-104$ 
Neugschwandtner R.W., Kaul H.P., 2014. Sowing ratio and N fertilization affect yield and yield components ofoat and pea in intercrops. Field Crops Research, 155, pp.159-163

Peterson D.M., 2011. Storage proteins. In: Oats chemistry and technology. Webster F.H., Wood P.J (eds). pp. 123-142

Rakcejeva T., Skudra L., Zute S., Gramatina I., Kazanova V., 2007. Evaluation of nutritive value of wheat bread with biologically activated hull-less oat grain additive 4th International Congress Flour-Bread'07 and 6th Croation Congress of Cereal Technologists, Croatia, Opatia, Oktober 24-27, pp. 62-70.

Redaelli R., Sgrullettab, D., Scalfatib, G., De Stefanisb D., Cacciatorib, P., 2009. Naked Oats for Improving Human Nutrition: Genetic and Agronomic Variability of Grain Bioactive Components. Crop Science, Vol. 49 No. 4, p. 1431-1437

Tamm, I., Tamm, Ü., Ingver, A., 2008. Suviteraviljade mahumass ja seda mõjutavad tegurid. Agronoomia 2008. Tartu, lk 76-79. (in Estonien)

Tiwari U., Cummins E., 2012. Dietary exposure assessment of $\beta$-glucan in a barley and oat based bread. Food Science and Technology, vol 47, issue 2, pp. 413-420

Triboi, E., Triboi-Blondel, A. M.,2002. Productivity and grain or seed composition: A new approach to an old problem - Invited paper. European Journal of Agronomy, $16,163-186$

Zute S., Berga L., Vīcupe Z., 2012. Variability in endosperm $\beta$-glucan content of husked and naked oat genotypes. Acta Biological University Daugavpilensis 11 (2), 2011, pp.192-200.pp.

Zute, S., Gruntina, M., 2008. Breeding of oat varieties in Latvia for food industry. Proceeding of the 18th EUCARPIA General Congress,,Modern variety breeding for present and future, needs.", 9-12 September, Valencia, Spain, pp. 662-666.

Zute S., Vicupe Z., Gruntina M., 2010. Factors influencing oat grain yield and quality under growing conditions of West Latvia, Agronomy Resaerch Nr. 8 (Special Issue III), pp 749-754

Wood P., 2011. Oat $\beta$-glucan: properties and function. In: Oats chemistry and technology. Webster F.H., Wood P.J (eds). pp. 219-254

Winfield, K., Hall, M. and Paynter, B., 2007. Milling oat and feed oat quality- what are the differences? <http://archive.agric.wa.gov.au/objtwr/imported_assets/ content/fcp/cer/oat/oat_grain_quality.pdf > (accessed 08/09/2014) 